Makale türü/Article type: Araştırma/Research

\title{
Faaliyet Giderlerinin Kârlılığa Etkisi: İmalat Sanayi Üzerine Bir İnceleme
}

\author{
$* * *$ \\ Effect of Operating Expenses on Profitability: An Investigation on Manufacturing Industry
}

\author{
Ersin Yenisu \\ Ankara Hacı Bayram Veli Üniversitesi, ersinyenisu@gmail.com \\ ORCID: 0000-0002-0235-4270
}

\begin{abstract}
Özet
21. yüzyılda imalat sanayi işletmelerinin varlıklarını sürdürebilmeleri için etkin bir gider kontrolü yapmaları zorunludur. Nitekim işletmeler rekabet üstünlüğü kazanabilmek için genel olarak ya maliyetlerini azaltmalı ya da daha yüksek kalite düzeyini yakalamalıdırlar. Bu çalışmanın amacı Türk imalat sanayi firmalarının faaliyet giderleri ile kârlılıkları arasındaki ilişkileri açıklamaktır. Çalışmada özellikle hangi faaliyet giderinin kârllık üzerindeki etkisi daha yüksektir sorusuna yanıt aranmaya çalışılmıştır. Bu doğrultuda çalışmada 1996-2015 yılsonu verileriyle söz konusu ilişki çoklu doğrusal regresyon analiziyle test edilmiştir. Regresyon ve diğer analiz araçlarıyla elde edilen bulgulara göre pazarlama harcamaları ile kârlılık arasında pozitif yönlü ve istatistiksel açıdan anlamlı bir ilişki gözlemlenmiştir. Sonuç olarak işletmeler pazarlamayı sadece reklam yapmak olarak algılamamalı lojistik, halkla ilişkiler, marka değeri, kurumsal sosyal sorumluluk vd. gibi unsurlara önem vererek pazarlama faaliyetlerini daha profesyonel olarak gerçekleştirmelidirler.
\end{abstract}

Anahtar Kelimeler: Faaliyet Giderleri, Kârlılık, Çoklu Doğrusal Regresyon Analizi

JEL Sinıflandirması: M10, M20, C02

\begin{abstract}
In the 21st century, manufacturing industry enterprises have to carry out an effective expenditure control in order to survive. As a matter of fact, in order to gain a competitive advantage, companies should either reduce their costs or achieve a higher quality level. The aim of this study is to explain the relationship between operating expenses and profitability of Turkish manufacturing industry firms. In this study, it is tried to answer especially the question of which activity cost has a higher impact on profitability. In this respect, the relationship between 1996 and 2015 was tested by multiple linear regression analysis. According to the findings obtained by regression and other analysis tools, a positive and statistically significant relationship between marketing expenditures and profitability was observed. As a result, businesses should not perceive marketing as just advertising but should perceive marketing as logistics, public relations, brand value, corporate social responsibility and so on. Moreover, businesses must do marketing activities more professionally.
\end{abstract}

Keywords: Operating Expenses, Profitability, Multiple Linear Regression Analysis

JEL Classification: M10, M20, C02

\section{GíRiş}

Sanayi devrimi tüm dünyada üretim ilişkilerini ve toplumsal ilişkileri kökten değiştirmiştir. Nitekim sürekli ilerleyen süreçte üretimde emeğin yerini makine gücü almıştır. Emek yoğun çalışan küçük işletmeler birleşerek ya da tasarruf sahiplerinden gelen sermaye birikimiyle büyük ölçekli işletmeler kurulmuştur. Günümüz her ne kadar bilgi toplumu olma yönünde ilerlese de sanayi halen önemini korumaktadır. Şüphesiz ki ülkelerin ekonomik açıdan farklı gelişim aşamalarında olması sanayi üretiminin gerekliliğine ayrı bir anlam katmaktadır. Henüz gelişmekte olan bir ülke olan Türkiye için de sanayi altyapısı, yatırımları ve verimliliği halen vazgeçilmezdir. Bu nedenle özellikle değer artırıcı unsurlar açısından imalat sanayi incelenmeye değerdir. 
İşletmeler için etkin bir maliyet kontrolü son derece önemlidir. Nitekim maliyetlerde düşüşü gerçekleştirmek için diğer giderler gibi faaliyet giderlerinin izlenmesi zaruridir. Bu nedenle ARGE, pazarlama ve yönetim giderlerinin özellikle uzun vadede işletmelerin geleneksel amacı olan kârlılık üzerindeki etkisi değerlendirilmelidir. Bu çalışmada Türkiye örneği üzerinden imalat sanayinde faaliyet giderleri ve kârlılık ilişkisi araştııılmıştır. Çalışmanın amacı imalat sanayinde faaliyet giderleri ve kârlılık ilişkisini ampirik bir uygulamayla test etmektir. Çalışmanın literatürden farklılığ ise grafiksel analizler ve ekonometrik analizlerle söz konusu ilişkilerin bir bütünlük içerisinde araştırılmasıdır. Bu çalışma özellikle imalat sanayi ve faaliyet giderleri konusunda genel bir çerçeve sunması açısından literatüre katkıda bulunabilir. Fakat bu çalışmada elde edilen bulguları genelleştirmek adına unutulmamalıdır ki her ülkenin, her alt sektörün ya da her işletmenin kendine özel bir durumu vardır. Diğer bir ifadeyle yukarıda değinilen genel çerçeve konusunun detayları olabileceği gibi söz konusu çerçeve daha üst bir bütünün de parçasıdır.

Bir sonraki bölümde imalat sanayi işletmelerinde kâr ve faaliyet giderleri TCMB sektör bilançoları verileri kullanılarak oluşturulan grafiksel gösterimlerle incelenmeye çalışılmıştır. Çalışmanın üçüncü bölümüyse faaliyet giderleri ve kârlılık ilişkilerini inceleyen yerli ve yabancı literatürden örneklere ayrılmıştır. İzleyen bölümde de çalışmada kullanılan veri seti ve kapsama değinilmiştir. Beşinci ve son bölümdeyse analiz sonuçları raporlanmış ve bulgular değerlendirilmiştir.

\section{1. İMALAT SANAYİ İŞLETMELERINDE KÂR VE FAALIYYT GIDERLERİ}

İmalat sanayi hemen hemen her ülke için genel ekonomik faaliyetler açısından önemli bir yere sahiptir. Nitekim günümüzde dışa açık bir ülke olan Türkiye'nin ihracat ve ithalat kalemlerinde imalat sanayi birinci sırayı almaktadır. Diğer yandan araştırmacılara göre üretim olmadan istikrarlı bir ekonomik büyüme olmaz. $\mathrm{Bu}$ nedenle bir ülkede üretimin en önemli lokomotifi olan imalat sanayi gerek süreç iyileştirmesi gerekse elde edilen sonuçlar açısından muhakkak her daim incelenmelidir. Bu amaç doğrultusunda TCMB sektör bilançolarını derlemekte ve işletmelere dair verileri araştırmacıların kullanımına sunmaktadır.

Aşağıda imalat sanayinin genel görünümü ve faaliyet giderleriyle kâr ilişkisi grafiklerle açıklanmaya çalışılacaktır. İlk olarak TCMB'nin internet adresinden alınan ölçeğe göre firma sayıları Grafik 1'de sunulmuştur.

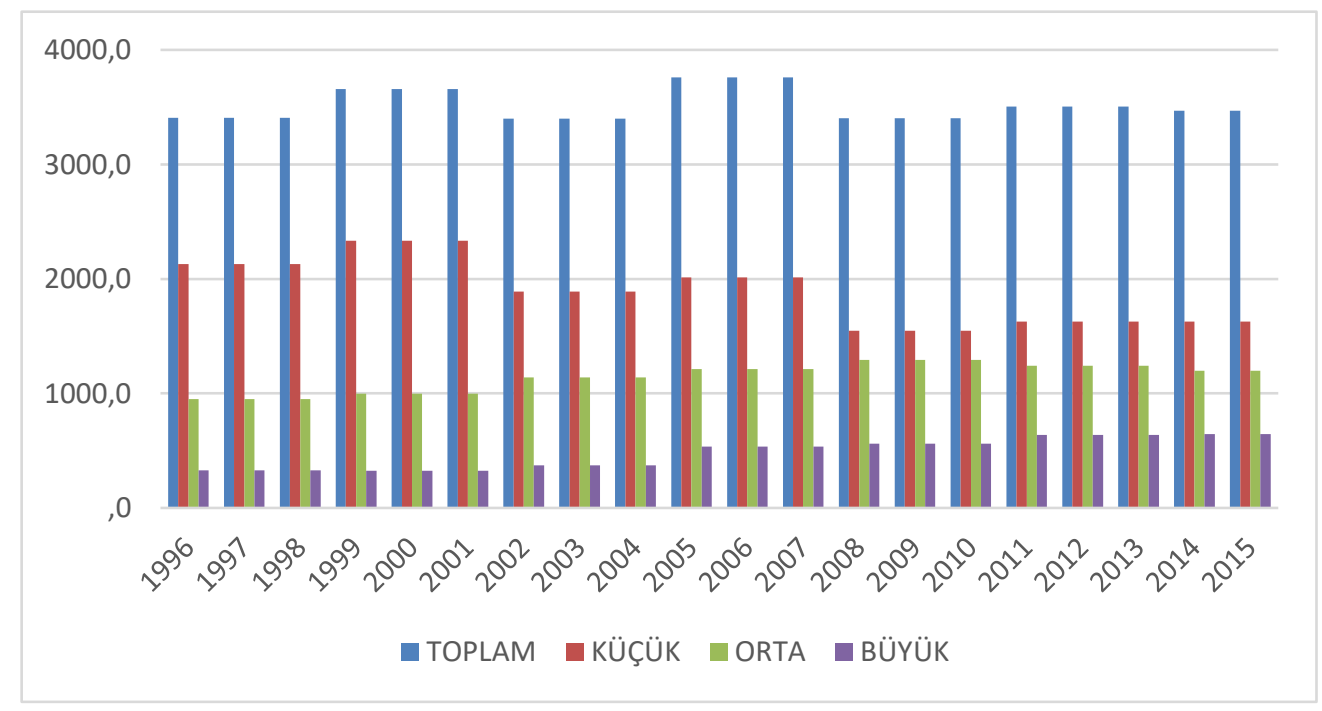

Grafik 1. TCMB Sektör Bilançolarına Göre Firma Sayıları (1996-2015)

(Kaynak: TCMB Sektör Bilançoları)

Grafik 1'e göre 1996-2015 arası Türkiye'de imalat sanayi toplam firma sayısında önemli bir değişimin olmadığı görülmektedir. Bununla birlikte 2001 krizinin ve 2008 küresel finansal krizin etkileri Grafik 1'den 
açıkça görülmektedir. Diğer taraftan Grafik 1'e göre küçük ölçekli firma sayısında 1996-2015 yılları itibariyle dikkate değer bir azalma olduğu, orta ölçekli firma sayısında bir miktar artış olduğu ve nihayetinde büyük ölçekli firma sayısındaysa önemli bir artış olduğu söylenebilir.

İzleyen kısımda imalat sanayi toplam kâr ve alt kalemler itibariyle toplam faaliyet giderleri Grafik 2 aracılı̆̆ıyla gösterilmiştir.

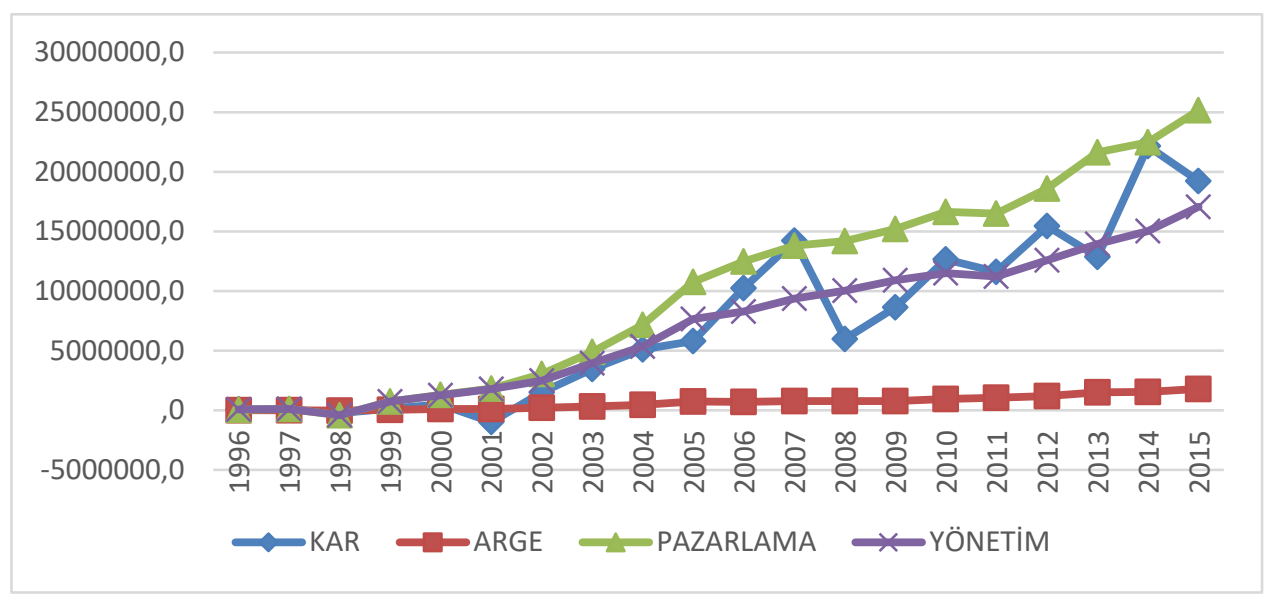

Grafik 2. İmalat Sanayi Toplam Kâr ve Toplam Faaliyet Giderleri (1996-2015)*

(Kaynak: TCMB Sektör Bilançoları), *Veriler deflatör ile reelleştirilmiş olup firma sayısı 2015 yılı itibariyle 3.469'dur.

Grafik 2'ye bakıldığında pazarlama giderlerinin 1996-2015 döneminde hızlı bir yükseliş gösterdiği görülmektedir. Yine yönetim giderleri de nispeten istikrarlı ve yüksek bir artış göstermiştir. Söz konusu dönemde ARGE giderleriyse çok düşük seyretmiştir. Hatta diğer faaliyet giderlerine nazaran yok denecek kadar azdır. Kârın ise istikrarsız bir yükseliş trendinde olduğu söylenebilir. Bu sonuçlara göre imalat sanayi işletmelerinde ARGE harcamaları çok düşüktür. Pazarlama, satış ve dağıtım giderlerindeyse dikkate değer bir artış söz konusudur.

İmalat sanayi işletmelerinin küçük, orta ve büyük ölçekli olmak üzere sınıflandırılarak incelenmesi çalışmamızın bulguları açısından önemlidir. Grafik 3'te küçük ölçekli imalat sanayi işletmelerinin toplam kâr ve toplam faaliyet giderleri sunulmuştur.

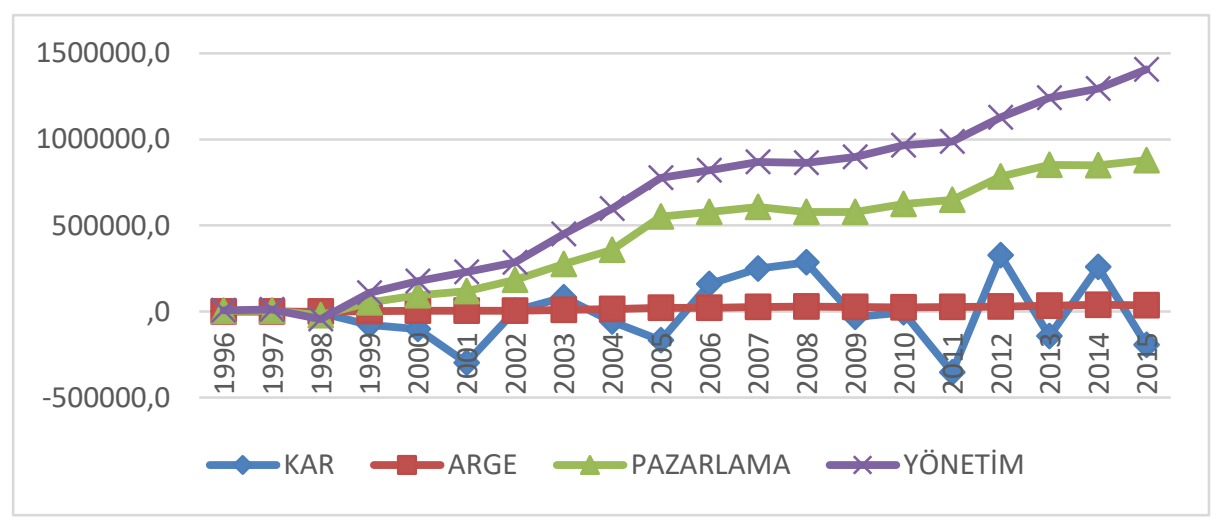

Grafik 3. Küçük Ölçekli İmalat Sanayi Toplam Kâr ve Toplam Faaliyet Giderleri (1996-2015)*

(Kaynak: TCMB Sektör Bilançoları), *Veriler deflatör ile reelleştirilmiş olup firma sayısı 2015 yılı itibariyle 1.628 'dir. 
Küçük ölçekli imalat sanayi işletmelerinde toplam kâr ve faaliyet giderlerine bakıldığında çok farklı bir tabloyla karşılaşmaktayız. Nitekim Grafik 3'e göre genel yönetim giderleri faaliyet giderleri içerisinde en hızlı artışı gösteren kalemdir. Pazarlama, satış ve dağıtım giderleriyse yine istikrarlı bir artışa sahiptir. ARGE giderleriyse genel toplamda olduğu gibi yine yok denecek kadar azdır. Grafik 3'e göre küçük ölçekli imalat sanayi işletmelerinde kâr aşırı istikrarsızdır ve genel toplama göre çok düşük seviyelerdedir. Bunun sebebi finansal istikrarsızlık olabileceği gibi küçük ölçekli işletmelerin düşük kârlılıkla çalışması da olabilir.

Grafik 4'te orta ölçekli imalat sanayi işletmelerinin toplam kâr ve toplam faaliyet giderleri görülmektedir.

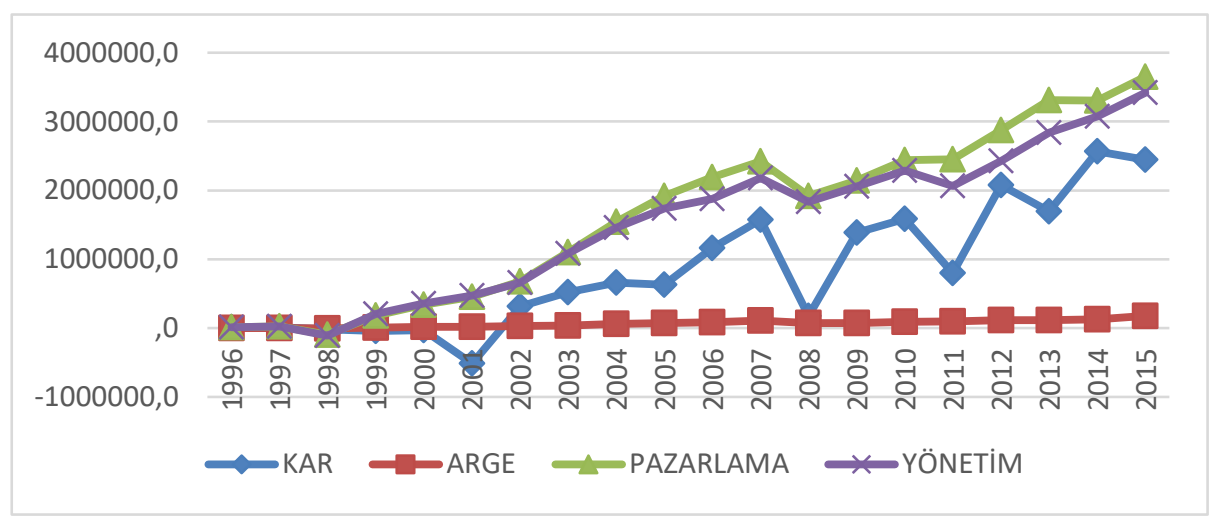

Grafik 4. Orta Ölçekli İmalat Sanayi Toplam Kâr ve Toplam Faaliyet Giderleri (1996-2015)* (Kaynak: TCMB Sektör Bilançoları), *Veriler deflatör ile reelleştirilmiş olup firma sayısı 2015 yılı itibariyle 1.197'dir.

Orta ölçekli imalat sanayi işletmelerinin toplam kâr ve alt kalemler itibariyle toplam faaliyet giderleri beklendiği üzere küçük ve büyük ölçekli işletmelerin grafiksel görünümünün ortasında yer almaktadır. Diğer bir ifadeyle Grafik 4'e göre ARGE giderleri çok düşük, pazarlama ve yönetim giderleri artış eğiliminde ve son olarak kâr istikrarsız bir artış eğilimi içindedir.

Büyük ölçekli imalat sanayi işletmelerinde toplam kâr ve alt kalemler itibariyle toplam faaliyet giderleri Grafik 5 'te sunulmuştur.

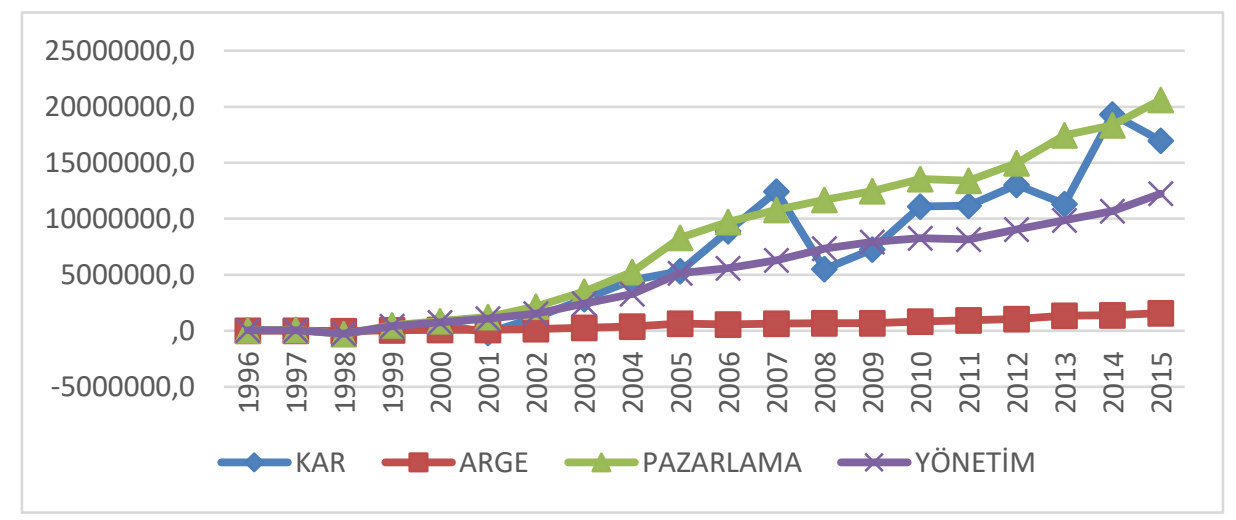

Grafik 5. Büyük Ölçekli İmalat Sanayi Toplam Kâr ve Toplam Faaliyet Giderleri (1996-2015)* (Kaynak: TCMB Sektör Bilançoları), *Veriler deflatör ile reelleştirilmiş olup firma sayısı 2015 yılı itibariyle 644'tür.

Grafik 5'e göre pazarlama, satış ve dağıtım giderlerindeki yükseliş faaliyet giderleri içerisinde en yüksektir. Yine genel yönetim giderlerinin nispeten istikrarlı bir artış eğilimi içerisinde olduğu görülmektedir. Diğer taraftan Grafik 5'e göre büyük ölçekli imalat sanayi işletmelerinde de kârın istikrarsız bir artış eğilimi 
gösterdiği söylenebilir. ARGE giderlerine bakıldığındaysa genel olarak düşük seyrettiği fakat küçük bir artış trendinin olduğu ileri sürülebilir.

Grafik 6'da imalat sanayi işletmelerinde firma büyüklüğüne göre toplam kârın eğilimi sunulmuştur.

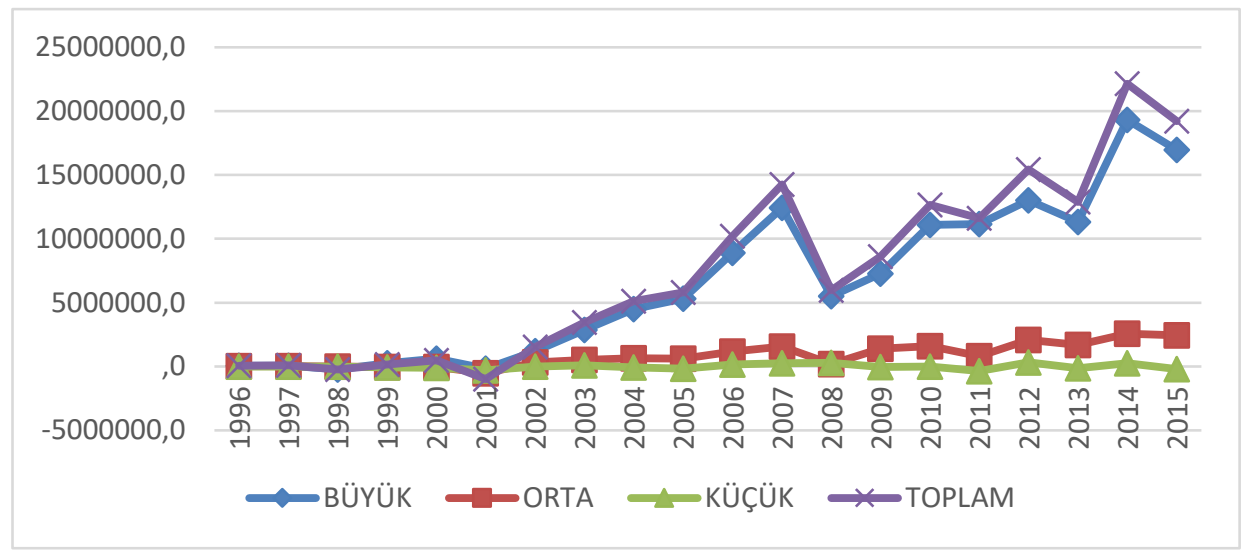

Grafik 6. Firma Büyüklüğüne Göre İmalat Sanayi Toplam Kâr Miktarları (1996-2015)*

(Kaynak: TCMB Sektör Bilançoları), *Veriler deflatör ile reelleştirilmiştir.

Grafik 6'dan imalat sanayi işletmelerinin ölçeğe göre kâr performansları görülebilir. Nitekim söz konusu grafiğe göre imalat sanayi işletmelerinin elde ettiği toplam kârın önemli bir kısmının büyük ölçekli firmalar tarafından yaratıldığı görülmektedir. Grafik 6'ya göre küçük ölçekli işletmeler çok düşük bir kâr oranıyla çalışmakta, orta ölçekli işletmeler nispeten daha yüksek bir kâr oranıyla çalışmakta ve son olarak büyük ölçekli işletmelerse genel toplamda elde edilen kârın büyük bir bölümünü oluşturmaktadırlar. Küçük işletmelerde büyük işletmelere göre finansal istikrarsızlığın ve kayıt dışılığın daha yüksek olması bu görünümü açıklamakta yardımcı olabilir.

\section{LITERATÜR İNCELEMESİ}

Faaliyet giderlerinin kârlılığa etkisi yerli ve yabancı literatürde uzunca bir süredir incelenmektedir. $\mathrm{Bu}$ kısımda faaliyet giderlerinin ayrı ayrı ya da toplu halde kârlılık ya da işletme performansı üzerindeki etkisini ele alan literatürden örnekler sunulacaktır.

Firmanın pazar değeri ile reklam ve ARGE giderleri ilişkisini inceleyen Cahuvin ve Hirschey (1993) çalışmalarında sektörden sektöre etki büyüklüğü değişmekle beraber söz konusu harcamaların firmaların piyasa değeri üzerinde olumlu bir etki yarattığını bulgulamışlardır. Söz konusu çalışmada ayrıca firma büyüklüğü arttıkça reklam ve ARGE giderlerinin etkinliğinin arttığı sonucuna varılmıştır. Diğer taraftan Archarungroj ve Hoshino (1999) konuyu daha da sınırlandırarak sadece ARGE harcamalarının kârlılığa etkisini incelemişler ve sonuç olarak 170 Japon firmasında ARGE harcamaları arttıkça kârlılık göstergelerinin yükseldiğini açıklamışlardır. Aynı çalışmada firmalar büyüdükçe ARGE yoğunluğunun arttı̆̆ gözlemlenmiştir. Bir diğer çalışmada Lee ve Griffith (2004) pazarlama harcamaları ile firma performansı ilişkisini araştırmışlar ve söz konusu iki değişken arasında pozitif bir ilişki olduğunu saptamışlardır. Archarungroj ve Hoshino (1999)'ya benzer olarak Kallunki vd. (2009) çalışmalarında ARGE harcamalarıyla şirket performansı konusunu incelemişler ve özellikle teknolojik birleşmelerin ve ele geçirmelerin ARGE potansiyelini arttırarak firma performansına olumlu etki ettiğini açıklamışlardır. Bununla birlikte firmaların ARGE harcamalarını ekonomik gelişme perspektifinde inceleyen Coad ve Rao (2010) şirketler büyüdükçe ARGE yatırımlarının arttığını gözlemlemişlerdir. Benzer şekilde Apergis and Sorros (2014) ABD enerji sektörünü incelemişler ve özellikle yenilenebilir enerji alanında faaliyet gösteren firmalarda ARGE harcamalarındaki artışın kârlılık üzerinde pozitif etkili olduğunu bulgulamışlardır. Bu 
sonuç yüksek teknolojik ürün üretilen sektörlerde ARGE harcamalarının etkinliğinin daha yüksek olduğu şeklinde de yorumlanabilir.

Çalışmasında konumuz üzerine genel bir değerlendirmeyi amaçlayan Çiftçi (2014) küçük, orta ve büyük ölçekli firmalarda faaliyet giderlerinin kârlılık üzerindeki etkisinin çoğunlukla pozitif olduğu sonucuna varmış ve özellikle orta ölçekli firmalarda ARGE giderlerinin kârlılık üzerindeki olumlu etkisine dikkat çekmiştir. Aynı şekilde ARGE giderlerinin kârlılık üzerindeki etkisini belirlemeyi amaçlayan Kocamış ve Güngör (2014) teknoloji şirketlerinde söz konusu ilişkinin pozitif olduğunu saptamışlardır. Diğer yandan Mahendru ve De (2014) çalışmalarında reklam harcamalarının kârlılık üzerinde olumlu etkisinin olduğunu belirtmişlerdir. $\mathrm{Bu}$ alanda yapılmış olan bir diğer çalışmada Banarjee ve Siddhante (2015) pazarlama iletişimi harcamaları ile kârlılık arasında çift yönlü bir ilişki olduğunu bulgulamışlardır. Çıtak (2015)'sa çalışmasında pazarlama yatırımları ile firma performansı ilişkisini incelemiş ve firmaların pazarlama faaliyetlerini geliştirerek etkinliklerini arttırabileceklerini ortaya koymuştur. Diğer taraftan Özen ve Kılınç (2015) halkla ilişkiler faaliyetlerinin firma performansı üzerindeki etkisini incelemişler ve halkla ilişkiler faaliyetleri arttıkça firmaların performanslarının da arttığı sonucuna varmışlardır. Daha önce değinilen araştırmalara benzer olarak Öztürk ve Zeren (2015) çalışmalarında ARGE harcamalarının satışların büyüme performansını arttırdığı bulgusuna ulaşmışlardır. Görüldüğü üzere literatürdeki birçok çalışmaya göre ARGE ve pazarlama harcamaları işletme performansı üzerinde olumlu etkiye sahiptir.

Yine geleneksel bir araştırma konusu olan ARGE ile kârlılık ilişkisini araştıran Akgün ve Akgün (2016) tek bir işletme üzerine yaptıkları analizle ARGE giderleri ile esas faaliyet kârı arasında uzun dönemli bir ilişki olduğu sonucuna varmışlardır. Akgün ve Akgün (2016)'ün çalışmalarını biraz daha genişleten Demirgüneş ve Üçler (2016)'se çalışmalarında ARGE harcamaları ile sektörel büyümenin eşbütünleşik olduğunu bulgulamışlardır. Yukarıda da görüleceği üzere ARGE giderleri ile firma performansı ilişkisinin pozitif yönlü olduğunu bulgulayan çok sayıda araştırma vardır. Söz konusu araştırmaların yanı sıra yakın zamanda aynı sonucu bulgulayan önemli miktarda araştırma yapılmıştır (Doğan ve Yıldız, 2016; Işık vd. 2016; Kıracı vd. 2016, Dağlı ve Ergün, 2017; Kayıhan ve Tepeli, 2017; Çağlak ve Çakır, 2018; Nazlı vd. 2018; Yıldırım ve Sakarya, 2018; Chen ve Ibhagui, 2019; Özer ve Gülençer, 2019; Özer vd., 2019). Bahsi geçen araştırmalarda yazarların genelllikle teknoloji yoğun sektörleri incelemeleri nedeniyle söz konusu ilişkinin pozitif çıkma olasılığı olduğu gibi söz konusu pozitif ilişkinin tüm çalışmalarda desteklenir olması da dikkate değerdir.

Bir diğer alt faaliyet gideri olan pazarlama harcamaları ile kârlılık ilişkisini inceleyen Geyikçi ve Mucan (2016)'sa reklam harcamalarının finansal performansa olan etkisini panel veri yöntemiyle incelemişlerdir. Söz konusu çalışma kapsamında yapılan analizler neticesinde pazarlama harcamalarının net satışlar ve kârlılık üzerinde yüksek bir etkiye sahip olduğu görülmüştür. Diğer taraftan Katherina vd. (2016) Kazakistan'da faaliyette bulunan en büyük 20 bankanın verilerini kullanarak pazarlama giderleri ve kârlılık ilişkisini incelemişler ve sonuç olarak pazarlama harcamalarındaki artışın bir dönem sonra bankaların kârlarını arttırdığını bulgulamışlardır. Bununla birlikte Öztürk ve Dülgeroğlu (2016) da pazarlama giderleri arttıkça kârlılığın da arttığı sonucuna ulaşmışlardır. Konuyu özetlemek gerekirse, tıpkı ARGE giderlerinin kârlılık üzerinde pozitif etkili olduğu şeklinde literatürde ortak bir görüşün var olması gibi pazarlama giderleri de çoğu araştırmada firma performansı üzerinde artırıcı bir etkiye sahiptir (Chowdhury, 2017; Kayıhan ve Tepeli, 2017; Ayrıçay ve Kılıç, 2018; Jaisinghani ve Kanjilal, 2019; Özer ve Gülençer, 2019). Bununla birlikte yapılan literatür incelenmesinde dikkati çeken bir diğer genel husus bazı çalışmalara göre işletmeler için pazarlama giderleri bir noktaya kadar kârlılık artışına yol açmakta bir noktadan sonraysa kârlılığı azaltmaktadır.

Yukarıdaki literatüre küçük bir katkı olarak bu çalışmada hangi faaliyet giderinin firma performansına daha fazla etki ettiği araştırılacaktır. Diğer bir deyişle faaliyet giderleri arasında kâr üzerindeki etki bakımından 
sıralama yapılmaya çalışılacaktır. Bu küçük katkının bir devamı olarak şüphesiz ki konunun alt sektörler bağlamında incelenmesiyle ilgi çekici sonuçlara ulaşılabilir.

\section{VERİ SETI VE KAPSAM}

Bu çalışmada Türkiye'de faaliyet gösteren 3469 imalat sanayi işletmesinin konsolide mali tablolarından elde edilen faaliyet giderleri ve kâr ilişkisi incelenmiştir." Veriler TCMB'nin internet sitesinden alınmış olup konsolide sektör mali tablolarından derlenmiştir. Tekdüzen muhasebe sistemine göre düzenlenmiş olan gelir tablosunda faaliyet giderleri;

- Araştırma ve Geliştirme Giderleri (ARGE)

- Pazarlama Satış ve Dağıtım Giderleri (Pazarlama)

- Genel Yönetim Giderleri (Yönetim)

den oluşmaktadır. "KÂR” ise hem gelir tablosunda hem de bilançoda gözüken ve vergi sonrası ortaya çıan rakam olan Dönem Net Kârı (Zararı)'dır.

TCMB'nin internet sitesindeki sektör bilançolarında sadece 1996-2015 y1lları mevcuttur. Bu nedenle buradaki analizlerde söz konusu yılsonları toplulaştırılmış bilanço ve gelir tablosu verileri kullanılmıştır. Söz konusu istatistiklerde sektörler büyüklüklerine göre (büyük, orta, küçük) ve alt sektörlere göre ayrılmıştır. Nitekim çalışmada yukarıda da görüldügü üzere büyük ölçekli, orta ölçekli ve küçük ölçekli imalat sanayi analizleri de yapılmıştır. Bu doğrultuda TCMB 50 kişiden az çalışanı olan firmayı "küçük ölçekli”, 50 ile 500 arası çalışanı olan firmayı "orta ölçekli" ve 500'den daha fazla çalışanı olan firmaları da "büyük ölçekli" olarak kabul etmektedir. Bununla birlikte TCMB'nin yine işletmelerin net satışlarına göre ölçeklendirme yaptığı da görülmektedir.

Diğer taraftan bu alandaki diğer çalışmalarda olduğu gibi bu çalışmada da verilerin analizinde Türkiye açısından kanaatimizce iki önemli sorun vardır. Birincisi makro veya mikro ölçekli verilerin Türkiye'de yıllar itibariyle aşırı istikrarsız bir seyir izlemesidir. Nitekim teoriye göre özellikle kırılma yılları sapmalı tahminlere yol açabilir. İkincisiyse enflasyonun satın alma gücündeki yarattığı değişimlerle analiz sonuçları açısından hatalı karşılaştırmalara ya da tutarsızlıklara neden olabilmesidir. Nihayetinde burada bahsedilen ikinci sorun olan enflasyon sorunu bu çalışmada veriler reelleştirilerek kısmen de olsa giderilmiştir. Kısacası belki de tüm bu nedenlerden dolayı Türkiye'yi konu alan araştırmacılar daha dikkatli olup bulgularını birden fazla yöntemle desteklemelidirler.

\section{ANALIZ VE BULGULAR}

Literatürde değişkenler arasındaki ilişkiyi ölçmeye yarayan ve bu amaç doğrultusunda en çok kullanılan yöntem regresyon analizidir. 1950'li yıllardan sonra bu alanda yeni yöntemler geliştirilmiş olsa da temel ilişkileri yansıtması bakımından regresyon analizi halen araştırmacılar tarafından sıklıkla kullanılmaktadır. Dahası klasik regresyon analizinin yeni geliştirilen bu yöntemlere açı bir şekilde temel oluşturduğu da bilinen bir gerçektir. Diğer taraftan matematiğin bilime katmış olduğu nesnellik nedeniyle sosyal bilimlerde özellikle uygulamalı çalışmalarda regresyon tekniği kullanılmaktadır. Bu çalışmada da çoklu doğrusal regresyon analizine dayanan bir zaman serisi analizi yapılacaktır.

Bu bölümde önce kullanılan verilerin genel görünümünü ortaya koymak amacıyla tanımlayıcı istatistiklere yer verilecektir. Hemen ardından değişkenler arasındaki ilişkilerin yönünü ve gücünü belirleyen korelasyon analizi yapılacaktır. Son olarak da çoklu doğrusal regresyon analiziyle kâr ve faaliyet giderleri arasındaki ilişki tahmin edilmeye çalışlacaktır.

Değişkenlere ilişkin tanımlayıcı istatistikler Tablo 1'de sunulmuştur. 
Tablo 1. Tanımlayıcı İstatistikler

\begin{tabular}{lcccccc}
\hline Değişken & Gözlem & En Küçük & En Büyük & Ortalama & $\begin{array}{c}\text { Standart } \\
\text { Sapma }\end{array}$ & Jarque-Bera \\
\hline Kâr & 20 & -2.094 .108 & 23.918 .038 & 8.164 .288 & 7.531 .602 & 1.310191 \\
Arge & 20 & 11.786 & 1.945 .201 & 735.225 & 581.662 & 1.311089 \\
Pazarlama & 20 & 242.710 & 27.285 .955 & 11.601 .365 & 8.695 .509 & 1.388731 \\
Yönetim & 20 & 244.359 & 18.512 .047 & 8.150 .406 & 5.645 .783 & 1.218450 \\
\hline
\end{tabular}

Tablo 1'e göre pazarlama serisi dört seri içerisinde standart sapması yani değişkenliği en yüksek olan seridir. Bu doğrultuda pazarlamayı sırayla kâr, yönetim ve ARGE giderleri serileri takip etmektedir. Serilerin ortalamalarına bakıldığındaysa pazarlama giderleri serisinin ortalaması en yüksektir. Bunu sırasıyla kâr, yönetim giderleri ve ARGE giderlerinin izlediği görülmektedir.

$\mathrm{Bu}$ sonuçlar genel olarak değerlendirildiğinde imalat sanayi firmalarının pazarlama giderlerinde yüksek denilebilecek bir istikrarsızlık olduğu ve ARGE giderlerininse en yüksek istikrara sahip olduğu söylenebilir. Diğer taraftan Tablo 1'den çıkarılacak bir diğer önemli sonuç ARGE giderlerinin diğer faaliyet giderleri ve kâra göre önemli derecede düşük olduğu ve pazarlama giderlerininse kârşılaştırmalı olarak yüksek olduğudur.

Tanımlayıcı istatistiklerden sonra değişkenler arasındaki ilişkinin yönünü ve gücünü belirlemek amacıyla korelasyon analizi yapılacaktır. İmalat sanayi firmalarının faaliyet giderleri ve kâr değişkenlerine ait korelasyon analizi sonuçları Tablo 2'de sunulmuştur.

Tablo 2. Korelasyon Analizi

\begin{tabular}{|c|c|c|c|c|c|}
\hline & & Kâr & ARGE & Pazarlama & Yönetim \\
\hline Kâr & $\begin{array}{l}\text { Pearson Korelasyon } \\
\text { [Olasilik] } \\
\mathrm{N}\end{array}$ & $\begin{array}{c}1 \\
20\end{array}$ & $\begin{array}{c}, 945 * * \\
{[, 000]} \\
20\end{array}$ & $\begin{array}{c}\text {,949** } \\
{[, 000]} \\
20\end{array}$ & $\begin{array}{l}, 943 * * \\
{[, 000]} \\
20\end{array}$ \\
\hline ARGE & $\begin{array}{l}\text { Pearson Korelasyon } \\
\text { [Olasilik] } \\
\mathrm{N}\end{array}$ & - & $\begin{array}{c}1 \\
20\end{array}$ & $\begin{array}{c}, 988 * * \\
{[, 000]} \\
20\end{array}$ & $\begin{array}{c}, 983 * * \\
{[, 000]} \\
20\end{array}$ \\
\hline Pazarlam & $\begin{array}{l}\text { earson Korelasyon } \\
\text { [Olasilık] } \\
\text { N }\end{array}$ & - & - & $\begin{array}{c}1 \\
20\end{array}$ & $\begin{array}{c}, 999 * * \\
{[, 000]} \\
20\end{array}$ \\
\hline Yönetim & $\begin{array}{l}\text { Pearson Korelasyon } \\
\text { [Olasılık] } \\
\text { N }\end{array}$ & - & - & - & $\begin{array}{c}1 \\
20\end{array}$ \\
\hline
\end{tabular}

Korelasyon analizi sonuçlarına göre öncelikle dört seri arasında ikili olarak güçlü bir ilişki vardır ve bu ilişkinin yönü pozitiftir. Diğer bir ifadeyle her bir serideki artış/azalış diğer üç seride artış/azalış yönünde etki bırakmaktadır. Bununla birlikte kâr değişkeni üzerinde en güçlü etkinin sırasıyla pazarlama giderleri, ARGE giderleri ve yönetim giderleri olduğu görülmektedir. Sonuç olarak, korelasyon analizine göre imalat sanayi firmaları açısından kârı en fazla etkileyen faaliyet giderleri sırayla pazarlama, ARGE ve yönetimdir. 
İzleyen bölümde yukarıdaki iki analiz yöntemi (tanımlayıcı istatistikler ve korelasyon analizi) çalışmanın nihai analiz yöntemi olan çoklu doğrusal regresyon analiziyle bir kez daha test edilecektir.

Cahuvin ve Hirschey (1993), Çiftçi (2014), Iş1k vd. (2016) ve Özer (2019)'e göre kurulan regresyon modeli şöyledir:

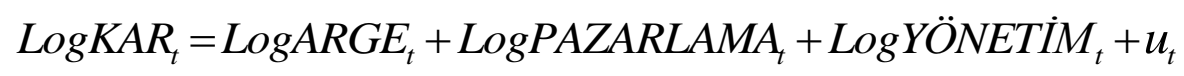

Yukarıdaki modelin tahmin edildiği çoklu doğrusal regresyon analizi sonuçları Tablo 3’te sunulmuştur.

Tablo 3. Çoklu Doğrusal Regresyon Analizi Sonuçları

\begin{tabular}{|c|c|c|c|c|}
\hline \multirow{2}{*}{$\begin{array}{l}\text { Bağımlı Değişken: LogKÂR } \\
\text { Bağımsız Değişkenler }\end{array}$} & \multicolumn{2}{|c|}{ Yöntem: En Küçük Kareler } & \multicolumn{2}{|c|}{ Örneklem: 1996-2015 } \\
\hline & $\underline{\text { Katsay } 1}$ & Standart Hata & $\underline{t \text { istatistiği }}$ & $\underline{\text { Olasilık }}$ \\
\hline & $-0,770266^{*}$ & 0.253374 & -3.040037 & 0.0074 \\
\hline LogARGE & $4.577535^{*}$ & 0.836891 & 5.469693 & 0.0000 \\
\hline LogPAZARLAMA & $-3.025079 *$ & 0.683727 & -4.424393 & 0.0004 \\
\hline LogYÖNETİM & & & & \\
\hline $\mathrm{R}^{2}$ & 0,979521 & Akaike Bilgi Kri & & 0.508234 \\
\hline Düzeltilmiş $\mathrm{R}^{2}$ & 0.977112 & Schwarz Kriteri & & 0.657594 \\
\hline Durbin-Watson İst. & 2.267601 & Hannan-Quin $\mathrm{K}_{\mathrm{I}}$ & & 0.537391 \\
\hline
\end{tabular}

*\%1 önem seviyesinde anlamlı. Jarque-Bera (Olasılık): 2.744597(0.253524), Breusch-Godfrey LM Testi (2):

0.6128, Heteroskedasticity (Değişen Varyans): 0.2268, Modelde doğrusallığın sağlanması ve değişen varyans sorununu gidermek için logaritmik değerler kullanılmıştır.

Yukarıdaki model tahmin edilmeden önce sabit katsayının bağımsız bir değişken olduğu model tahmin edilmiş olup söz konusu değişkenin katsayısı anlamlı olmadığı için, model seçim kriterlerine de bakılarak, Tablo 3'te sonuçları verilen sabitsiz model kullanılmıştır. Bununla birlikte normal dağılıma uygunluk, otokorelasyon ve değişen varyans gibi diagnostic (tanılayıc1) testler yapılmış olup modelin ekonometrik açıdan güvenilirliği sağlanmaya çalışılmıştır.

Bulguları değerlendirmek gerekirse; imalat sanayi firmalarının toplam kârları üzerinde faaliyet giderlerinin etkisini ölçmeyi amaçlayan çoklu doğrusal regresyon modeline göre tüm bağımsız değişkenlerin olasılık katsayıları 0.01'den küçük olduğu için üç değişken de istatistiksel açıdan anlamlıdır. Bununla birlikte modelin $\mathrm{R}^{2}$ 'si 0,97 'dir. Buna göre bağımsız değişkenler bağımlı değişkeni yaklaşık \%97 oranında açıklamaktadır. Diğer bir ifadeyle modelin genel olarak açıklama gücü oldukça yüksektir. Buna ek olarak LogARGE ve LogYÖNETIM değişkenlerinin katsayı işareti negatif, LogPAZARLAMA değişkeninin katsayı işaretiyse pozitiftir. Buna göre ARGE ve yönetim giderleri kâr üzerinde olumsuz, pazarlama giderleri kâr üzerinde olumlu bir etkiye sahiptir. Diğer taraftan yukarıdaki modelde olduğu gibi tam logaritmik denklemlerde katsayılar esneklikleri vermektedir. Buna göre ARGE harcamalarındaki \%1'lik bir artış kârı yaklaşı \% 0,7 azaltmakta, yönetim giderlerindeki \%1'lik bir artış kârı yaklaşı \% 3 azaltmakta ve pazarlama giderlerindeki \%1' lik bir artışsa kârı yaklaşık \%4,5 arttırmaktadır. Elde edilen bu bulgulardan özellikle ARGE giderleri ve genel yönetim giderlerinin kârlılık üzerinde negatif etki yaratmaları literatür açısından dikkat çekicidir. Bu negatif katsayıların nedeni sorgulandığındaysa olası bir açıklama bu iki alanda verimsiz yatırımlar ve liyakatsiz personel istihdamı olabilir. 
Sağlamlık açısından bakıldığında, literatürde genel olarak çoklu doğrusal regresyon analizinde bağımsız değişken sayısının en az 5 katı kadar örneklem hacmiyle yöntem uygulanabilirdir şeklinde yaygıın bir görüş vardır. Bu çalışmadaysa elde edilebilen gözlem sayısı 20'dir. Bu sayı ekonometrik açıdan yeterli olsa da sonuçların tutarlılığına ve sağlamlığına dikkat edilmelidir. Doğru bir analiz için bu örneklem sayısı yeterli olmasıyla birlikte bu çalışmada nihai sonuca varılırken yukarıda yapılan tüm analizlerin bulguları dikkate alınmıştır. Diğer bir ifadeyle grafiksel analiz bulguları, literatür incelemesi bulguları, tanımlayıcı istatistikler bulguları, korelasyon analizi bulguları ve nihayetinde çoklu regresyon analizi bulguları toplu olarak değerlendirilmiştir. Kısacası bu çalışmada bahsedilen incelemelerde genel olarak elde edilen bulgularla nihai sonuca gidilmeye çalışılmıştır.

\section{SONUÇ}

Faaliyet giderleri işletmeler açısından nispeten önemli sayılabilecek giderlerdendir. Bir ülkede ekonominin can damarı olan imalat sanayi işletmeleri mutlaka gider kontrolü yaparak kârlılıklarını bir üst seviyeye taşımalıdırlar. Teoride ve uygulamada faaliyet giderleri ile kârlılık ilişkisi uzunca bir süredir incelenmektedir. Bu çalışmada da söz konusu ilişkiler imalat sanayi sektörü bağlamında araştırılmaya çalışılmıştır.

Çalışmada elde edilen bulgulardan özellikle pazarlama, satış ve dağıtım giderlerinin kârlılık üzerinde yüksek bir etkinliğe sahip olduğu öne çıkmaktadır. Buna göre pazarlama harcamaları arttıkça işletmelerin performansları da büyük ölçüde artmaktadır. Bu bulgu Cahuvin ve Hirschey (1993), Çiftçi (2014), Chowdhury (2017), Kayıhan ve Tepeli (2017) Ayrıçay ve Kılıç (2018), Jaisinghani ve Kanjilal (2019) ve Özer ve Gülençer (2019)'in sonuçlarıyla uyuşmaktadır. Diğer taraftan yapılan çoklu doğrusal regresyon analizine göre ARGE giderleri literatürün aksine kârlılık üzerinde negatif bir etki yaratmaktadır. Literatürle uyumlu olmayan bu ilişkinin sebebi verimsiz ARGE yatırımları olabilir. Bununla birlikte çalışmamızda elde edilen bir diğer bulgu genel yönetim giderlerinin de kârlılık üzerinde negatif etkiye sahip olmasıdır. $\mathrm{Bu}$ ters yönlü ilişkinin de yine işletmelerin yönetim kademelerinde liyakata dayanmayan ve gereğinden fazla yapılan personel istihdamından kaynaklanmış olabileceği ileri sürülebilir.

Araştırmacılar bu çalışmanın konusunu farklı yönleriyle ele alabilirler. Bu doğrultuda özellikle Kamu Aydınlatma Platformu (KAP)'ndan temin edilecek daha güncel ve örnekleme yöntemleriyle seçilebilecek daha detaylı firma verileri alınarak panel veri analizi gibi nispeten daha tutarlı sonuçlar veren yöntemler kullanılarak sektör-alt sektör analizleri gerçekleştirilebilir.

Nihayetinde bu çalışmaya göre işletmeler rekabet üstünlügü sağlayabilmek ve uzun vadeli değer maksimizasyonunu gerçekleştirebilmek için mutlaka pazarlama faaliyetlerini gözden geçirmelidirler. Nitekim günümüzde pazarlamayı sadece reklam yapmak olarak algılamayarak lojistik, halkla ilişkiler, marka değeri, kurumsal sosyal sorumluluk, değere dayalı üretim, iç ve dış paydaşların memnuniyeti, müşteri sadakati vd. gibi konuları dikkate alarak profesyonel bir pazarlama anlayışını benimsemiş firmalar uzun vadede başarılı olabilirler.

\section{KAYNAKÇA}

Akgün, A. \& Akgün, V. Ö. (2016). İşletmelerde Ar-Ge Harcamalarının Kârlılığa Etkisi: Aselsan Örneği, Selçuk Üniversitesi Sosyal ve Teknik Araştırmalar Dergisi, 12, 1-12.

Apergis, N. \& Sorros, J. (2014). The Role of R\&D Expenses for Profitability: Evidence from U.S. Fossil and Renewable Energy Firms, International Journal of Economics and Finance, 6(3), 8-15.

Archarungroj, P. ve Hoshino, Y. (1999). Firm Size and R\&D on Profitability: An Empirical Analysis on Japanese Chemical and Pharmaceutical Industry, Japanese Journal of Administrative Science, 13(2), 71-86.

Ayrıçay, Y. \& Kilıç, M. (2018). Pazarlama Yoğunluğu ve Firma Performansi İlişkisi: BIST’de Bir Alan Araştirmasi, Ömer Halisdemir Üniversitesi İktisadi ve İdari Bilimler Fakültesi Dergisi, 11(1), 177-191. 
Banerje, N. \& Siddhanta: (2015). An Empirical Investigation on the Impact of Marketing Communication Expenditure on Firms' Profitability: Evidence from India, Global Business Review, 16(4), 609-622.

Çağlak, E. \& Çakır, H. M. (2018). Araştırma-Geliştirme Faaliyetlerinin Firma Kârlılı̆̆ı Üzerine Etkisi: BİST 100 Endeksinde Bir Uygulama, Pamukkale Journal of Euroasian Socioeconomic Studies, 5(2), 78-91.

Chauvin, K. W. \& Hirschey, M. (1993). Advertising, R\&D Expenditures and the Market Value of the Firm, Financial Management, 22(4), 128-140.

Chen, Y. \& Ibhagui, O. W. (2019). R\&D Investment-Firm Performance Nexus: New Evidence from NASDAQ Listed Firm, North American Journal of Economics \& Finance, 1-36.

Chowdhury: R. (2017). Measuring the Relationship among the Advertisement Expenditure, Sales Revenue and Profit on Steel Industries and Banking Industries in Bangladesh, European Journal of Business and Management, 9(9), 1-5.

Çiftçi, C. (2014). Türkiye İmalat Sanayiinde Ölçek Bazında Kârlılık ve Temel Giderler İlişkisi: 1998-2009 Dönemi, Sosyoekonomi, 2, 229-252.

Çıtak, L. (2015). Pazarlama Yatirimlarinin Finansal Performans Üzerindeki Etkisi ve Borsa İstanbul KOBİ Sanayi Endeksi Firmalarinin Etkinliklerinin Değerlendirilmesi, Erciyes Üniversitesi İktisadi ve İdari Bilimler Fakültesi Dergisi, 45, 49-68.

Coad, A. \& Rao, R. (2010). Firm Growth and R\&D Expenditure, Economics of Innovation and New Technology, 19(2), 127-145.

Dağl1, H. \& Ergün, T. (2017). Türkiye'de Ar-Ge Harcamalarinin Firma Kârliliğina Etkisi, KTÜ Sosyal Bilimler Enstitüsü Sosyal Bilimler Dergisi, 7(13), 69-83.

Demirgüneş, K. \& Üçler, G. (2016). Ar-Ge Yatırımları ve Büyüme: İmalat Sektörü Üzerine Ampirik Bir Çalışma, İstanbul Üniversitesi İşletme Fakültesi Dergisi, 45(1), 53-64.

Doğan, M. \& Yıldız, F. (2016). Araştirma ve Geliştirme Harcamalarinin (Arge) Firma Kârliliği Üzerindeki Etkisi: BİST’te İşlem Gören İmalat Sanayi Firmalari Üzerine Bir Araştirma, Kastamonu Üniversitesi İktisadi ve İdari Bilimler Fakültesi Dergisi Eylül, 14, 178-187.

Geyikçi, U. B. \& Mucan, B. (2016). Reklam Harcamalarinin Finansal Duruma Olan Etkisinin Panel Veri Analizi Yöntemiyle Ölçümü, Sosyal Bilimler Dergisi, 50, 68-85.

Işık, N., Engeloğlu, Ö. \& Kılınç, E. C. (2016). Araştirma ve Geliştirme Harcamalarinin, Kârlilik ve Satişlar Üzerindeki Etkisi: Borsa İstanbul Firmalari Üzerine Bir Uygulama, Erciyes Üniversitesi İktisadi ve İdari Bilimler Fakültesi Dergisi, 47, 27-46.

Jaisinghani, D. \& Kanjilal, K. (2019). Marketing Investments and Firm Performance in Manufacturing Sector: A Panel Threshold Model for China, Journal of the Asia Pacific Economy, 24(1), 117-126.

Kallunki, J. P., Pykko, E. \& Laamenen, T. (2004). Stock Market Valuation, Profitability and R\&D Spending of the Firm: The Effect of Technology Mergers and Acquisitions, Journal of Business Finance \& Accounting, 36(7) $\&(8), 838-862$.

Katenova, M., Dumlupınar, B. \& Efe, İ. (2016). Relation of Marketing and Profitibality of Kazakhstan Banks, Niğde Üniversitesi İktisadi ve İdari Bilimler Fakültesi Dergisi, 9(3), 239-247.

Kayıhan, B. \& Tepeli, Y. (2017). Faaliyet Giderlerinin İşletme Kârliliği Üzerindeki Etkisi: BIST Metal Eşya, Makine ve Gereç Yapim Sektöründe Bir Araştirma, Mehmet Akif Ersoy Üniversitesi Sosyal Bilimler Enstitüsü Dergisi, 9(20), 327-337.

Kıracı, M., Çelikay, F. \& Çelikay, D. (2016). The Effects of Firms' R\&D Expenditures on Profitability: An Analysis with Panel Error Correction Model for Turkey, International Journal of Business and Social Science, 7(5), 233-240.

Kocamış, T. U. \& Güngör, A. (2014). Türkiye'de Ar-Ge Harcamaları ve Teknoloji Sektöründe Ar-Ge Giderlerinin Kârlılık Üzerine Etkisi: Borsa İstanbul Uygulaması, Maliye Dergisi, 166, 127-138.

Lee, C. \& Griffith, D.A. (2004). The Marketing Strategy-Performance Relationship in an Export-Driven Developing Economy, International Marketing Review, 21(3), 321-334.

Mahendru, M. \& De, K.K. (2014). Does Advertising Expenditure Impact Firm Value: A Case of Indian FMCG Industry, Global Journal of Management and Business Research Finance, 14(1), 6-18. 
Nazlı, E. \& Özer, İ. D. ve Yanıktepe, B. (2018). Ar-Ge Giderlerinin Kârlılık ve Net Satışlara Etkisinin Bir Analizi: Kocaeli İli Örneği, 5th International Congress on Political, Economic and Social Studies (ICPESS), 79-89.

Özen, E. \& Kılınç, F. (2015). İşletmelerde Finansal Performansın Artmasında Halkla İlişkilerin Rolü ve Halkla İlişkiler Algısı, Optimum Ekonomi ve Yönetim Bilimleri Dergisi, 2(1), 147-17.

Özer, A., Öztürk, M. \& Özer, N. (2019). BİST İmalat Sanayi Firmalarının Araştırma ve Geliştirme Giderlerinin Piyasa Değeri ve Firma Kârlılı̆̆ Üzerindeki Etkisi, Muhasebe ve Finansman Dergisi, 82, 135-146.

Özer, M. \& Gülençer, İ. (2019). İşletmelerin Ar-Ge ve Pazarlama Harcamalarinin Pay Değeri Üzerindeki Etkisi, Kafkas Üniversitesi İktisadi ve İdari Bilimler Fakültesi Dergisi, 10(19), 52-73.

Öztürk, E. \& Dülgeroğlu, İ. (2016). Pazarlama ve Genel Yönetim Giderlerinin Firma Performansi Üzerindeki Etkisi, Niğde Üniversitesi İktisadi ve İdari Bilimler Fakültesi Dergisi, 9(3), 136-146.

Öztürk, E. \& Zeren, F. (2015). The Impact of R\&D Expenditure on Firm Performance in Manufacturing Industry: Further Evidence from Turkey, International Journal of Economics Research, 6(2), 32-36.

Sevüktekin, M. \& Nargeleçekenler, M. (2010), Ekonometrik Zaman Serileri Analizi: E-Views Uygulamall, Ankara: Nobel.

TCMB Sektör Bilançoları (2019). https://www.tcmb.gov.tr/ adresinden alındı.

Yıldırım, H. H. \& Sakarya, Ș. (2018). Firmalarin Ar-Ge Harcamalarinin Aktif ve Özsermaye Kârliliğina Etkisi: BIST Teknoloji Sektöründe Bir Uygulama, İşletme Bilimi Dergisi, 6(3), 39-60.

Yıldırtan, D. Ç. (2011), E-Views Uygulamalı Temel Ekonometri: Makro Ekonomik Verilerle, Türkmen. 